\title{
Risiko Kejadian Perdarahan Pasca Rawat Inap pada Penggunaan Bersamaan Warfarin dan Antibiotik
}

(Post-hospitalization bleeding risk in association with concomitant use of warfarin and antibiotics)

\author{
Nazulanita Rahma*, Tri Murti Andayani \& Arief Nurrochmad \\ Fakultas Farmasi Universitas Gadjah Mada, Jl. Sekip Utara, Senolowo, Sinduadi, Kec. Mlati, Kabupaten Sleman,

\begin{abstract}
Concomitant use of warfarin and antibiotics is known to increase bleeding risk. Major bleeding related to warfarin use can be fatal and lead to patient's death. This research aimed to analyze the interaction of warfarin with antibiotics and its effect on bleeding event at the first hospital visit following inpatient discharge in RSUD Wates. This was a retrospective cohort study of 67 warfarin uses in inpatient settings with/without antibiotic coadministration. All the data including diagnosis, medication in use, laboratory test results, and bleeding event at hospitalization and first hospital visit were extracted from the patient's medical record from January 2018 to September 2020. Statistical analysis was performed using Chi-square test or Fisher exact test and Independent t-test or Mann Whitney $U$ test. Statistical difference was found in the bleeding event throughout seven days following inpatient discharge between antibiotic and control group (16\%; $0 \% ; p=0.017)$. Antibiotics related to the bleeding event were azithromycin, ampicillin-sulbactam, cephalosporins, and quinolones. Types of the bleeding event were hematemesis melena $(25 \%)$, hematuria $(50 \%)$, and unknown (25\%). This study concludes that concurrent use of warfarin and antibiotics in hospitalized patients may influence the risk of bleeding events for seven days post-hospitalization.
\end{abstract}

Keywords: warfarin; antibiotics; bleeding; post-hospitalization.

ABSTRAK: Penggunaan warfarin dan antibiotik bersamaan diketahui dapat meningkatkan risiko perdarahan. Kejadian perdarahan mayor terkait warfarin dapat berupa perdarahan fatal hingga menyebabkan kematian. Penelitian ini bertujuan untuk menganalisis interaksi warfarin dan antibiotik dan efeknya terhadap kejadian perdarahan pada pemeriksaan pertama pasca rawat inap di RSUD Wates. Desain studi berupa kohort retrospektif pada 67 kasus penggunaan warfarin dengan/tanpa antibiotik oleh pasien rawat inap. Data berupa diagnosis, terapi, pemeriksaan pendukung, dan kejadian perdarahan saat rawat inap hingga pemeriksaan pertama diambil dari rekam medik pasien tertanggal Januari 2018 hingga September 2020. Analisis data dilakukan secara statistika menggunakan uji Chi-square atau uji Fisher exact test dan uji independent $t$-test atau uji Mann Whitney $U$ test. Terdapat perbedaan bermakna pada kejadian perdarahan dalam waktu tujuh hari pasca rawat inap antara kelompok antibiotik dan kontrol (16\%; 0\%; $p=0.017)$. Antibiotik yang digunakan oleh pasien dengan kejadian perdarahan yaitu azitromisin, ampisilin-sulbaktam, golongan sefalosporin, dan golongan kuinolon. Kejadian perdarahan yang terjadi meliputi hematemesis melena (25\%), hematuria (50\%), tidak diketahui (25\%). Studi ini menyimpulkan bahwa penggunaan bersamaan warfarin dan antibiotik saat rawat inap dapat berpengaruh terhadap kejadian perdarahan dalam waktu tujuh hari setelah pasien dipulangkan.

Kata kunci: warfarin; antibiotik; perdarahan; pasca rawat inap.

\section{Pendahuluan}

Warfarin adalah antikoagulan oral yang masih banyak digunakan hingga saat ini. Warfarin merupakan satusatunya antikoagulan penghambat vitamin $\mathrm{K}$ (Vitamin $K$ antagonist, VKA) yang masuk dalam Formularium Nasional [1]. Tujuan pemberian warfarin adalah untuk mencegah kejadian trombosis tanpa disertai dengan kejadian perdarahan [2]. Kejadian perdarahan mayor pada penggunaan warfarin dapat berupa perdarahan fatal yang dapat berakibat pada kematian [3,4]. Untuk mencegah hal tersebut, perlu dilakukan pemantauan terapi warfarin agar konsisten berada dalam rentang INR (international normalized ratio) yang ditargetkan, umumnya berkisar pada rentang 2,0-3,0 [5]. Nilai INR >4 dikaitkan dengan risiko kejadian perdarahan mayor [6]. Dalam mencapai tujuan ini, ada beberapa hal yang menjadi pertimbangan. Warfarin memiliki jendela terapi yang sempit, menunjukkan variasi hubungan dosis-respon yang beragam antar pasien karena faktor genetik, dan

\section{Article history}

Received: 21 Jan 2021 Accepted: 02 Juni 2021 Published: 05 Agust 2021

Access this article

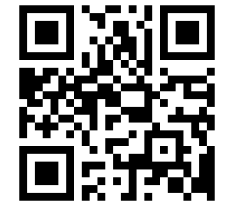


sangat rentan terhadap interaksi obat maupun makanan [7]. Berbagai studi telah menunjukkan bahwa interaksi obat dapat mempengaruhi aktivitas antitrombotik warfarin yang diperlihatkan dengan perubahan nilai INR maupun timbulnya kejadian perdarahan [8-11]. Mekanisme interaksi obat ini dapat terjadi pada tahap absorpsi atau metabolisme warfarin ataupun vitamin $\mathrm{K}$ serta pada tahap sintesis hingga eliminasi dari faktor koagulasi [12].

Antibiotik adalah salah satu golongan obat yang dilaporkan dapat berinteraksi dengan warfarin. Metronidazol, mikonazol, dan flukonazol dapat meningkatkan nilai INR $>4[9,10]$. Penggunaan bersamaan warfarin dengan amoksisilin, azitromisin, dan antibiotik golongan kuinolon seperti siprofloksasin, levofloksasin, dan moksifloksasin juga berisiko meningkatkan nilai INR [13]. Berbagai studi juga melaporkan adanya peningkatan kejadian perdarahan pada pemberian bersamaan warfarin dengan kotrimoksazol [9,14,15]. Risiko tinggi kejadian perdarahan juga dikaitkan dengan penggunaan bersamaan warfarin dengan seftriakson $[14,16,17]$. Mekanisme interaksi warfarin dengan antibiotik ini dapat terjadi melalui induksi atau inhibisi pada enzim pemetabolisme warfarin serta pada gangguan sintesis vitamin $\mathrm{K}$ oleh bakteri normal di usus [11]. Kenaikan nilai INR tertinggi terjadi pada waktu $10-12$ hari dihitung dari hari ketujuh setelah paparan pertama dengan antibiotik [10]. Namun studi lain juga menunjukkan bahwa kejadian admisi karena perdarahan pada pasien dengan terapi warfarin dapat disebabkan oleh paparan antibiotik selama 60 hari sebelum rawat inap [14].

Beberapa studi mengenai warfarin menggunakan subjek Indonesia telah dilakukan $[18,19]$. Studi tersebut memaparkan adanya interaksi obat yang mungkin berpengaruh terhadap capaian nilai INR [18] maupun kejadian perdarahan [19]. Namun demikian, penelitian sebelumnya ini dilakukan dengan desain studi cross-sectional dan tidak menggunakan kelompok kontrol [19]. Studi kali ini dilakukan dengan membandingkan kelompok pasien dengan interaksi warfarin-antibiotik dengan kelompok pasien tanpa interaksi warfarin-antibiotik untuk melihat hubungannya dengan kejadian perdarahan pasca rawat inap pada populasi Indonesia.

\section{Metode Penelitian}

\section{Rancangan Penelitian}

Studi dilakukan menggunakan desain kohort retrospektif terhadap penggunaan bersamaan warfarin dan antibiotik pada pasien rawat inap di RSUD Wates, Yogyakarta. Studi dilakukan pada bulan Oktober hingga
November 2020 menggunakan data pasien dari tanggal 1 Januari 2018 hingga 30 September 2020. Paparan dari studi adalah penggunaan antibiotik pada pasien dengan terapi warfarin yang sedang menjalani rawat inap. Luaran dari studi adalah kejadian perdarahan pasca rawat inap yang dinilai pada saat pasien melakukan pemeriksaan pertama di rumah sakit dalam rentang waktu 7 hari sesudah dipulangkan. Waktu 7 hari ditetapkan berdasarkan studi sebelumnya yang menyatakan bahwa nilai INR tertinggi terkait interaksi warfarin dan antibiotik terjadi dalam rentang $10-12$ hari setelah hari ketujuh penggunaan bersamaan warfarin dan antibiotik [10]. Waktu 7 hari pasca rawat inap juga masih sesuai dengan penelitian yang menyatakan bahwa paparan antibiotik dalam waktu 60 hari sebelum rawat inap masih terkait dengan kejadian admisi dengan perdarahan pada pasien dengan terapi warfarin [14]. Selain itu, waktu 7 hari juga terkait dengan waktu kontrol pasca rawat inap yang dijadwalkan pada rencana kepulangan pasien. Penelitian ini telah melalui persetujuan oleh Komisi Etik Fakultas Kedokteran, Kesehatan Masyarakat, dan Keperawatan Universitas Gadjah Mada dengan nomor protokol KE/FK/1010/EC/2020.

\section{Populasi dan Sampel}

Populasi penelitian ini adalah pasien rawat inap dengan terapi warfarin dengan/tanpa antibiotik periode 1 Januari 2018 hingga 30 September 2020 di RSUD Wates. Kriteria inklusi yang ditetapkan yaitu pasien berusia $\geq 18$ tahun, tercatat melakukan pemeriksaan ke rumah sakit dalam waktu tujuh hari pasca rawat inap, serta tercatat telah mengonsumsi warfarin sebelum rawat inap. Pasien yang baru memulai terapi warfarin hanya dilibatkan jika pasien diresepkan warfarin selama minimal 5 hari saat rawat inap. Pasien dengan diagnosis masuk perdarahan serta memiliki riwayat penyakit kanker dan hati dieksklusi dari penelitian. Pasien kemudian dikelompokkan berdasarkan penggunaan antibiotik saat rawat inap. Pasien dengan penggunaan antibiotik dikategorikan sebagai kelompok antibiotik dan pasien tanpa penggunaan antibiotik dikategorikan sebagai kelompok kontrol. Pengambilan sampel dilakukan dengan teknik consecutive sampling. Berdasarkan studi pendahuluan menggunakan 10 subjek dari masing-masing kelompok, dapat dihitung besar sampel minimal. Proporsi kejadian perdarahan pada kelompok antibiotik adalah 3 kasus dan pada kelompok kontrol adalah 0 kasus. Dengan menggunakan rumus besar sampel uji hipotesis dua proporsi [20], diperoleh besar sampel minimal yaitu 21 kasus untuk setiap kelompoknya.

Semua pasien yang masuk dalam kriteria kemudian diamati sejak rawat inap hingga pasien melakukan 
pemeriksaan pertama di rumah sakit yang terjadi dalam rentang waktu tujuh hari sesudah pasien dipulangkan. Pasien pada kelompok antibiotik diamati sejak hari pertama penggunaan bersamaan warfarin dan antibiotik, sementara pasien pada kelompok kontrol diamati sejak hari pertama penggunaan warfarin. Pasien yang tidak mempunyai riwayat penggunaan warfarin sebelum rawat inap mulai diamati pada hari kelima pemberian warfarin. Luaran klinik yang dicatat adalah kejadian perdarahan saat pemeriksaan pertama pasien ke rumah sakit pasca rawat inap. Seluruh data yang diketahui dapat berpengaruh terhadap luaran klinik diambil dan dibandingkan antar dua kelompok, meliputi data usia, jenis kelamin, hasil pemeriksaan laboratorium, penyakit penyerta, dan pengobatan yang diberikan.

\section{Analisis Data}

Data kejadian perdarahan diambil dari catatan rekam medik pasien, baik saat kunjungan ke poliklinik maupun ke unit gawat darurat. Kejadian perdarahan didefinisikan sebagai semua kejadian perdarahan, baik minor maupun mayor yang bukan merupakan kejadian perdarahan akibat trauma. Faktor yang dapat berpengaruh terhadap kejadian perdarahan seperti usia, jenis kelamin, indikasi penggunaan warfarin, penyakit penyerta juga dibandingkan antar kelompok. Adapun penyakit penyerta yang dapat berpengaruh antara lain gagal jantung, stroke, gangguan ginjal, diabetes, trombositopenia, anemia, riwayat operasi, demam, dan leukositosis. Gagal jantung, stroke, diabetes, dan riwayat operasi dinilai berdasarkan diagnosis yang tertera pada rekam medik, sementara gangguan ginjal dinilai berdasarkan diagnosis atau adanya penurunan klirens kreatinin yang diperoleh dari pemeriksaan laboratorium. Kondisi trombositopenia, anemia, dan leukositosis juga dinilai berdasarkan pemeriksaan laboratorium. Kondisi demam dilihat dari pemeriksaan suhu pasien. Rentang nilai laboratorium dijabarkan lebih lanjut pada keterangan Tabel 1. Semua data diperoleh dari catatan rekam medik pasien.

Data demografi dan karakteristik pasien dianalisis secara deskriptif dan dinyatakan sebagai jumlah

Tabel 1. Data demografi dan karakteristik pasien

\begin{tabular}{|c|c|c|c|c|}
\hline Karakteristik & $\begin{array}{l}\text { Kohort total } \\
\qquad(N=67)\end{array}$ & $\begin{array}{l}\text { Kelompok Antibiotik } \\
\qquad(n=25)\end{array}$ & $\begin{array}{c}\text { Kelompok Kontrol } \\
(n=42)\end{array}$ & nilai $p$ \\
\hline \multicolumn{5}{|c|}{ Data demografi, jumlah (\%) } \\
\hline Usia, rata-rata (SD) & $65,5(12,6)$ & $70,3(13,1)$ & $62,8(11,5)$ & $0,017^{*}$ \\
\hline Jenis kelamin wanita, jumlah (\%) & $27(40,3)$ & $8(32)$ & $19(45,2)$ & 0,417 \\
\hline \multicolumn{5}{|c|}{ Indikasi warfarin, jumlah (\%) } \\
\hline $\mathrm{AF}$ & $57(85)$ & $20(80)$ & $37(88,1)$ & 0,482 \\
\hline VTE & $6(9)$ & $4(16)$ & $2(4,8)$ & 0,186 \\
\hline LV thrombus & $4(6)$ & $1(4)$ & $3(7,1)$ & 1,000 \\
\hline \multicolumn{5}{|c|}{ Penyakit penyerta, jumlah (\%) } \\
\hline Gagal jantung & $58(86,6)$ & $20(80)$ & $38(90,5)$ & 0,277 \\
\hline Stroke & $11(16,4)$ & $8(32)$ & $3(7,1)$ & $0,014^{*}$ \\
\hline Gangguan ginjal & $8(11,9)$ & $8(32)$ & $0(0)$ & $0,000^{*}$ \\
\hline Diabetes & $8(11,9)$ & $6(24)$ & $2(4,8)$ & $0,045^{*}$ \\
\hline Trombositopenia $(<150,000 / \mu \mathrm{L})$ & $2(3,0)$ & $0(0)$ & $2(4,8)$ & 0,525 \\
\hline Anemia (berdasarkan nilai $\mathrm{Hb})^{a}$ & $34(50,7)$ & $16(64)$ & $18(42,9)$ & 0,155 \\
\hline Anemia (berdasarkan nilai Hct) ${ }^{b}$ & $6(9,0)$ & $5(20)$ & $1(2,4)$ & $0,024^{*}$ \\
\hline Riwayat operasi & $3(4,5)$ & $3(12)$ & $0(0)$ & $0,048^{*}$ \\
\hline Demam $\left(>38^{\circ} \mathrm{C}\right)$ & $9(13,4)$ & $8(32)$ & $1(2,4)$ & $0,001^{*}$ \\
\hline 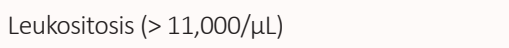 & $17(25,4)$ & $13(52)$ & $4(9,5)$ & $0,000^{*}$ \\
\hline Riwayat penggunaan warfarin sebelum admisi & $51(76,1)$ & $13(52)$ & $38(90,5)$ & $0,001 *$ \\
\hline
\end{tabular}

Keterangan: $\mathrm{AF}=$ Atrial fibrillation , VTE $=$ Venous thromboembolism $; \mathrm{LV}=$ left ventricular $\mathrm{Hb}=$ hemoglobin; Hct $=$ hematokrit; $\mathrm{a}=\mathrm{Nilai}$ hemoglobin $<13 \mathrm{~g} / \mathrm{dL}$ untuk pasien laki-laki dan $<12 \mathrm{~g} / \mathrm{dL}$ untuk pasien wanita; $\mathrm{b}=$ Nilai hematokrit $<30 \%$; $*=$ nilai $\mathrm{p}<0,05$ 
(persentase), rata-rata (SD), dan median (IQR) sesuai dengan sebaran datanya. Data ini juga dibandingkan antar kelompok untuk melihat apakah terdapat perbedaan yang bermakna secara statistik menggunakan uji Chi-square atau uji Fisher exact test untuk data berbentuk katagorikal dan uji independent t-test atau Mann Whitney $U$ test untuk data berbentuk kontinyu. Luaran klinik berupa kejadian perdarahan disajikan dalam bentuk jumlah (persentase) dan dibandingkan menggunakan uji Chi-square atau uji Fisher exact test. Semua analisis statistika dilakukan menggunakan IBM SPSS edisi 22. Perbedaan bermakna didefinisikan sebagai nilai $\mathrm{p}<0,05$ dengan tingkat kepercayaan 95\% untuk semua analisis.

\section{Hasil dan Diskusi}

Tercatat penggunaan warfarin dengan/tanpa antibiotik bersamaan yang sesuai dengan kriteria inklusi dan eksklusi sebanyak 67 kasus. Sebanyak 25 kasus adalah penggunaan bersamaan warfarin dan antibiotik dan 42 kasus lainnya adalah penggunaan warfarin tanpa antibiotik. Gambar 1 menunjukkan diagram alir penelitian ini.

Tabel 1 merangkum data demografi dan karakteristik dasar pasien. Terdapat perbedaan bermakna pada sebaran usia antara kelompok antibiotik dan kontrol. Kejadian perdarahan yang dialami pasien dengan terapi antikoagulan umumnya terjadi pada pasien usia lanjut [21-23]. Pasien usia lanjut lebih berisiko mengalami kejadian perdarahan dibanding pasien usia dewasa walaupun terapi antikoagulannya menunjukkan kendali yang lebih baik, diperlihatkan dari hasil pemantauan INR yang berada dalam rentang terapetik [22]. Usia lanjut (> 65 tahun) juga dikatakan sebagai faktor risiko kejadian perdarahan gastrointestinal pada studi lainnya [23]. Tidak terdapat perbedaan bermakna pada sebaran jenis kelamin dan indikasi penggunaan warfarin antar kedua kelompok. Penelitian sebelumnya mengungkapkan bahwa wanita lebih rentan terhadap kejadian perdarahan serta merupakan faktor yang secara independen terkait dengan kejadian INR $\geq 5,0$ [11,24]. Pasien dengan katup jantung mekanik menunjukkan sensitivitas yang lebih tinggi terhadap terapi VKA [5], namun pada studi ini tidak ada pasien dengan indikasi tersebut. Pasien dengan VTE (venous thromboembolism) disebutkan memiliki risiko kejadian perdarahan yang lebih tinggi dibandingkan pasien dengan AF (atrial fibrillation). Hal ini mungkin terkait dengan perbedaan proporsi penyakit penyerta serta durasi penggunaan antikoagulan [25].

Sebaran penyakit penyerta antar kelompok memperlihatkan perbedaan bermakna pada jenis penyakit stroke, gangguan ginjal, diabetes, anemia (berdasarkan nilai hematokrit), riwayat operasi, demam, dan leukositosis. Riwayat stroke, gangguan ginjal, diabetes, anemia, dan riwayat operasi merupakan faktor risiko kejadian perdarahan pada terapi antikoagulan untuk VTE [21]. Kejadian perdarahan mayor pada pasien dengan AF biasanya disertai dengan adanya penyakit gagal jantung, stroke, gangguan ginjal/hati, dan anemia [26]. Terdapat

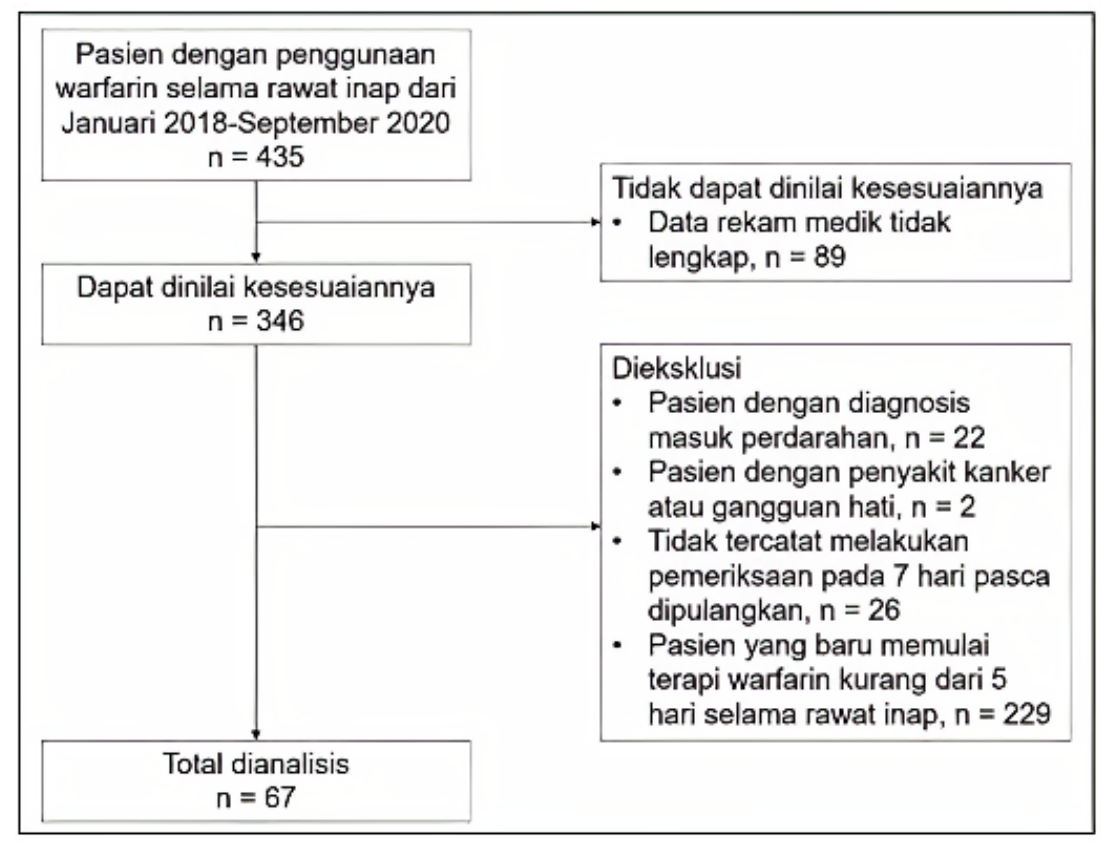

Gambar 1. Diagram alir penelitian 
Tabel 2. Data penggunaan obat lain

\begin{tabular}{|c|c|c|c|c|}
\hline \multirow[t]{2}{*}{ Karakteristik } & $\begin{array}{l}\text { Kohort total } \\
\qquad(N=67)\end{array}$ & $\begin{array}{l}\text { Kelompok Antibiotik } \\
\qquad(\mathrm{n}=\mathbf{2 5})\end{array}$ & $\begin{array}{l}\text { Kelompok Kontrol } \\
\qquad(n=42)\end{array}$ & \multirow[t]{2}{*}{ nilai $p$} \\
\hline & \multicolumn{3}{|c|}{ jumlah (\%) } & \\
\hline Penggunaan obat yang berinteraksi saat rawat inap ${ }^{a, b}$ & $35(52,2)$ & $18(51,5)$ & $17(48,5)$ & $0,022^{*}$ \\
\hline $\begin{array}{l}\text { Penggunaan obat dengan potensiasi aktivitas warfarin saat rawat } \\
\text { inap }^{a}\end{array}$ & $22(32,8)$ & $14(63,6)$ & $8(36,3)$ & $0,004^{*}$ \\
\hline Penggunaan obat dengan risiko perdarahan saat rawat inap ${ }^{b}$ & $24(35,8)$ & $12(50)$ & $12(50)$ & 0,18 \\
\hline Penggunaan obat yang berinteraksi saat pulang ${ }^{a, b}$ & $18(26,9)$ & $11(61,1)$ & $7(38,9)$ & $0,031^{*}$ \\
\hline Penggunaan obat dengan potensiasi aktivitas warfarin saat pulang ${ }^{a}$ & $9(13,4)$ & $7(77,8)$ & $2(22,2)$ & $0,011^{*}$ \\
\hline Penggunaan obat dengan risiko perdarahan saat pulang ${ }^{\mathrm{b}}$ & $9(13,4)$ & $3(33,3)$ & $5(55,6)$ & 0,718 \\
\hline
\end{tabular}

Keterangan: ${ }^{\mathrm{a}}=$ Fluoksetin, mikonazol (semua rute pemberian), amiodaron, flukonazol, nistatin, parasetamol, omeprazol, \& alopurinol; ${ }^{\mathrm{b}}=\mathrm{AINS}$ (antiinflamasi non steroid), penghambat selektif COX-2 (cyclooxygenase-2), antikoagulan, dan antiplatelet; $*=$ nilai $\mathrm{p}<0,05$

dugaan bahwa infeksi dan komplikasinya, meliputi demam, leukositosis, dan penurunan asupan vitamin $\mathrm{K}$, juga berpengaruh terhadap kejadian perdarahan $[15,27]$.

Tabel 2 menampilkan sebaran penggunaan obatobatan lain yang dilaporkan dapat berinteraksi dengan warfarin. Penggunaan obat-obat lain yang dapat berinteraksi dengan warfarin dibedakan berdasarkan mekanisme interaksinya. Fluoksetin, mikonazol (semua rute pemberian), amiodaron, flukonazol, nistatin, parasetamol, omeprazol, dan alopurinol digolongkan ke dalam obat yang dapat mempotensiasi aktivitas warfarin. Obat-obat yang termasuk dalam golongan ini dilaporkan oleh beberapa studi dapat mempengaruhi aktivitas antikoagulasi melalui penghambatan enzim pemetabolisme warfarin [8,10,28]. Karbamazepin dan flukloksasilin dimasukkan dalam golongan obat yang dapat menghambat aktivitas warfarin karena dapat menginduksi enzim pemetabolisme warfarin [5,10]. Obatobat yang memiliki potensi menyebabkan perdarahan digolongkan tersendiri, meliputi AINS (antiinflamasi non steroid), penghambat selektif COX-2 (cyclooxygenase-2), antikoagulan, dan antiplatelet $[5,8,28]$. Pada studi ini, terdapat perbedaan bermakna pada penggunaan obatobatan yang dapat berinteraksi secara keseluruhan antar dua kelompok, baik saat masih rawat inap $(p=0,022)$ maupun saat dipulangkan ( $\mathrm{p}=0,031)$. Meski begitu, saat dilakukan penggolongan berdasarkan mekanisme interaksinya, penggunaan bersamaan obat-obatan yang memiliki potensi perdarahan sendiri tidak menunjukkan adanya perbedaan yang signifikan antar dua kelompok. Pada studi ini juga tidak terdapat penggunaan obat-obatan yang dapat menghambat aktivitas antitrombotik warfarin, yaitu karbamazepin dan flukloksasilin.

Hasil luaran klinik utama ditunjukkan dalam Tabel 3. Tidak ada perbedaan bermakna pada durasi observasi antar kelompok dengan median durasi observasi selama 8 hari. Terdapat empat kejadian perdarahan yang terjadi pada pemeriksaan pertama di rumah sakit pasca rawat inap, semuanya berasal dari kelompok antibiotik. Empat kejadian perdarahan tersebut berupa hematemesis melena (25\%), hematuria (50\%), dan tidak diketahui (25\%). Pada kejadian hematemesis melena, pasien menjalani rawat inap kembali dengan diagnosis masuk berupa anemia gravis, hematemesis melena, dan CKD (chronic kidney disease).

Tabel 3. Kejadian perdarahan

\begin{tabular}{|c|c|c|c|c|}
\hline \multirow[t]{2}{*}{ Luaran } & $\begin{array}{l}\text { Kohort total } \\
\qquad(N=67)\end{array}$ & $\begin{array}{l}\text { Kelompok Antibiotik } \\
\qquad(\mathrm{n}=25)\end{array}$ & $\begin{array}{l}\text { Kelompok Kontrol } \\
\qquad(n=42)\end{array}$ & \multirow[t]{2}{*}{ nilai p } \\
\hline & \multicolumn{3}{|c|}{ jumlah (\%) } & \\
\hline Durasi observasi, median (IQR) & $8(4)$ & $8(3)$ & $8(1)$ & 0,745 \\
\hline $\begin{array}{l}\text { Kejadian perdarahan pada pemeriksaan pertama pasca rawat inap, } \\
\text { n (\%) }\end{array}$ & $4(5,9)$ & $4(16)$ & $0(0)$ & $0,017^{*}$ \\
\hline Kejadian perdarahan saat rawat inap, $\mathrm{n}(\%)$ & $3(4,5)$ & $3(12)$ & $0(0)$ & $0,048 *$ \\
\hline
\end{tabular}

Keterangan: $*=$ nilai $\mathrm{p}<0,05$ 
Pasien anemia dilaporkan menunjukkan peningkatan risiko terhadap kejadian perdarahan mayor sebesar 1,9 kali dibandingkan dengan pasien tanpa anemia yang mendapatkan terapi antikoagulan [29]. Pasien dengan terapi warfarin dan penurunan fungsi ginjal (eGFR $<15$ $\mathrm{mL} /$ menit/1,73 $\mathrm{m}^{2}$ ) juga memperlihatkan peningkatan risiko 10 kali lipat untuk mengalami kejadian perdarahan dibandingkan pasien dengan fungsi ginjal normal [30]. Dua kejadian perdarahan lain yaitu hematuria dan tidak diketahui mendapatkan intervensi berupa penyesuaian dosis warfarin sementara satu kejadian sisanya yaitu hematuria tidak diberikan intervensi. Menurut klasifikasi perdarahan GUSTO (Global Use of Strategies to Open Occluded Coronary Arteries) [31], tiga kejadian perdarahan selain hematemesis melena dapat dikategorikan sebagai perdarahan ringan sedangkan kejadian hematemesis melena dapat dikategorikan sebagai perdarahan sedang. Apabila dilihat berdasarkan tipe perdarahannya, perdarahan gastrointestinal merupakan tipe perdarahan paling umum yang ditemukan pada pasien dengan warfarin [9]. Terdapat

Tabel 4. Penggunaan antibiotik saat rawat inap dan saat dipulangkan serta tipe infeksi pada kelompok antibiotik

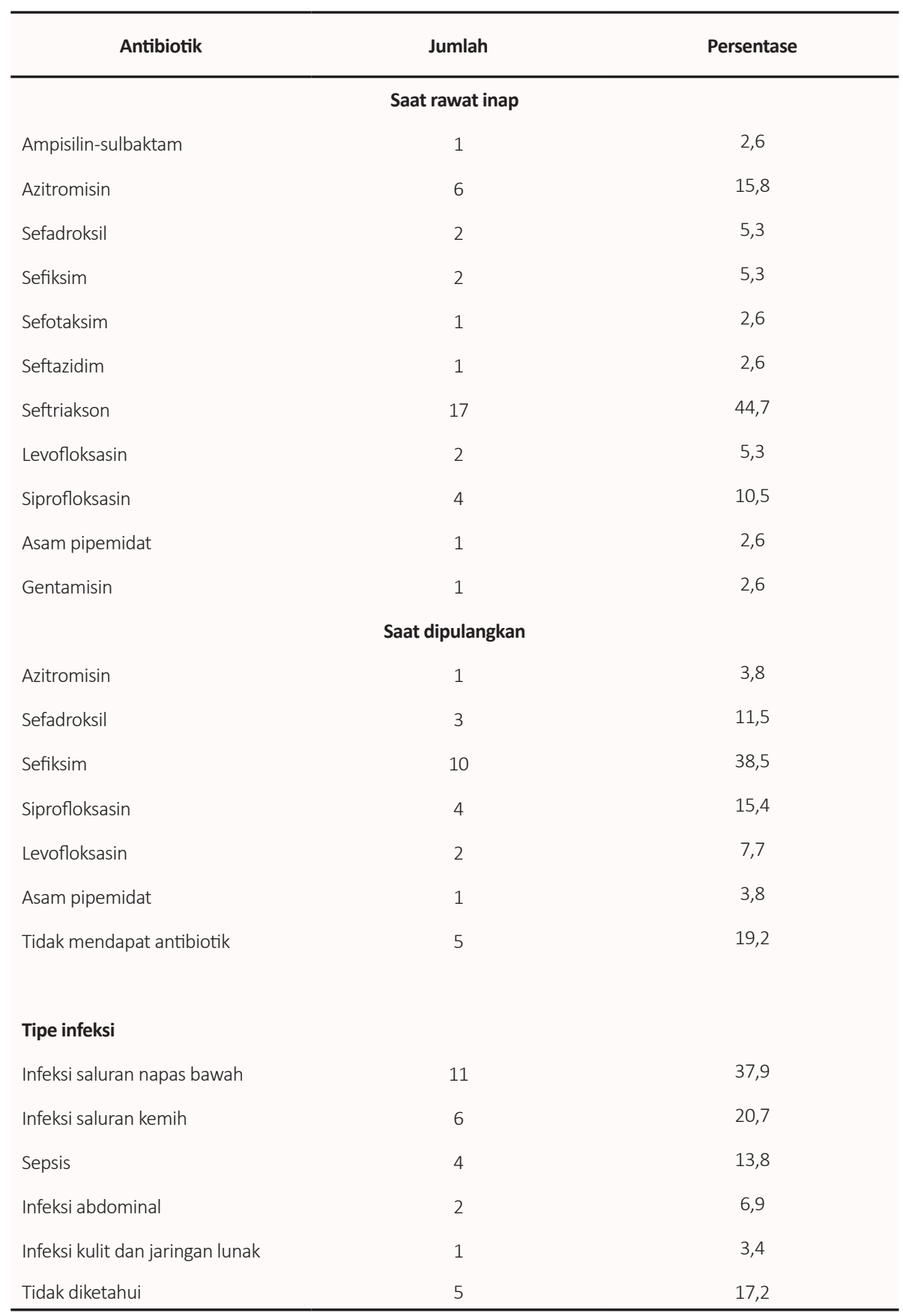


perbedaan bermakna pada kejadian perdarahan saat rawat inap pada kedua kelompok. Dari tiga kejadian perdarahan saat rawat inap, dua di antaranya mengalami kejadian perdarahan saat pemeriksaan pertama di rumah sakit. Riwayat perdarahan, terutama pada bagian gastrointestinal, dilaporkan meningkatkan risiko kejadian perdarahan selanjutnya pada pasien dengan terapi antikoagulan [23]. Riwayat perdarahan juga termasuk salah satu faktor risiko kejadian perdarahan dengan terapi antikoagulan pada pasien VTE [21].

Jenis antibiotik yang digunakan pasien saat rawat inap dan saat dipulangkan dirangkum pada Tabel 4. Seftriakson merupakan antibiotik yang paling sering digunakan saat rawat inap $(44,7 \%)$. Terdapat 6 penggunaan antibiotik kombinasi, yaitu kombinasi seftriakson dan azitromisin. Terdapat 7 penggunaan antibiotik lebih dari satu yang beririsan dengan antibiotik kombinasi saat rawat inap, yaitu seftriakson, azitromisin, dan siprofloksasin; seftriakson dan seftazidim; seftriakson, azitromisin, dan sefiksim; seftriakson, gentamisin, dan azitromisin; seftriakson dan siprofloksasin; seftriakson, azitromisin, dan siprofloksasin, serta sefotaksim dan sefadroksil. Masing-masing kombinasi tersebut terjadi pada satu pasien. Apabila dikelompokkan berdasarkan golongan antibiotiknya, maka diperoleh data penggunaan antibiotik yaitu sefalosporin $(60,5 \%)$ kuinolon (18,4\%), makrolida (15,8\%), penisilin (2,6\%), dan aminoglikosida (2,6\%). Sefiksim merupakan antibiotik terbanyak yang diresepkan saat pasien dipulangkan (38,5\%). Terdapat 5 pasien yang tidak memperoleh antibiotik saat dipulangkan. Jenis antibiotik saat rawat inap dan saat dipulangkan yang digunakan oleh pasien dengan kejadian perdarahan ditampilkan dalam Tabel 5 . Tiga pasien memperoleh antibiotik golongan sefalosporin dengan dua diantaranya merupakan kombinasi dengan azitromisin. Satu pasien menggunakan antibiotik ampisilin-sulbaktam. Antibiotik yang diresepkan saat pasien dipulangkan yaitu siprofloksasin dan sefiksim, masing-masing pada satu pasien. Dua pasien lainnya tidak diresepkan antibiotik saat dipulangkan.

Menurut studi sebelumnya, terdapat hubungan antara antibiotik yang terdapat dalam studi ini dengan kejadian perdarahan maupun peningkatan INR pada pasien yang mengonsumsi warfarin $[9,14,15,17]$. Peningkatan INR secara bermakna ditemukan pada pasien yang menggunakan seftriakson untuk indikasi infeksi saluran kemih di rawat inap [17]. Risiko kejadian perdarahan juga dilaporkan meningkat dengan adanya peresepan sefalosporin [14]. Pada pasien yang menggunakan azitromisin bersamaan dengan warfarin, sebuah studi mengungkapkan terjadinya peningkatan risiko kejadian perdarahan [9]. Hal yang sama juga dilaporkan terjadi pada penggunaan makrolida secara keseluruhan $[10,14]$. Antibiotik golongan kuinolon termasuk siprofloksasin dan levofloksasin juga dilaporkan dapat meningkatkan risiko kejadian perdarahan [9,14,32]. Meskipun demikian, masih terdapat perbedaan pendapat mengenai hal ini. Beberapa studi menyebutkan bahwa penggunaan siprofloksasin dan levofloksasin tidak mempengaruhi aktivitas antikoagulasi oleh warfarin [33,34]. Dalam studi ini, terdapat satu pasien dengan kejadian perdarahan pasca rawat inap yang menggunakan siprofloksasin saat rawat inap dan dipulangkan. Sebelum menggunakan siprofloksasin, pasien tercatat menggunakan kombinasi antibiotik seftriakson dan azitromisin. Dalam studi sebelumnya yang mengamati kejadian peningkatan nilai INR pada beberapa kelompok antibiotik, antibiotik yang digunakan sebagai acuan adalah antibiotik yang pertama digunakan [17] sehingga apabila diterapkan pada studi ini, maka antibiotik yang dikaitkan dengan kejadian perdarahan adalah kombinasi setriakson dan azitromisin. Pasien keempat menggunakan antibiotik ampisilinsulbaktam, yang secara khusus belum pernah dilaporkan sebagai antibiotik yang meningkatkan risiko kejadian perdarahan. Meski demikian, studi sebelumnya melaporkan bahwa penggunaan penisilin, termasuk amoksisilin dan amoksisilin-klavulanat, dapat memperbesar risiko kejadian perdarahan dan peningkatan nilai INR [13,14,35]. Ampisilin dan amoksisilin merupakan antibiotik aminopenisilin yang memiliki kemiripan struktur, sifat fisika-kimia, dan farmakologi [36] sehingga tidak menutup kemungkinan memiliki efek yang mirip terhadap aktivitas antikoagulasi warfarin. Antibiotik golongan aminoglikosida, dalam studi ini adalah gentamisin, juga belum pernah dibicarakan sebagai jenis antibiotik yang dapat mempengaruhi aktivitas antikoagulasi warfarin. Dalam studi ini gentamisin tidak termasuk dalam antibiotik yang digunakan oleh pasien yang mengalami kejadian perdarahan pasca rawat inap.

Mekanisme pasti yang terlibat dalam interaksi warfarin dan antibiotik masih menjadi perdebatan. Meskipun demikian, terdapat dugaan bahwa penghambatan sintesis vitamin $\mathrm{K}$ oleh bakteri normal usus menjadi salah satu mekanisme yang dapat mempengaruhi aktivitas antikoagulasi warfarin $[11,17,35]$. Seftriakson dieliminasi via empedu dan ditemukan dalam konsentrasi yang lebih tinggi pada usus sehingga diasumsikan akan lebih mungkin mengganggu produksi vitamin $\mathrm{K}$ oleh flora normal usus tersebut [17]. Antibiotik siprofloksasin juga merupakan penghambat kuat enzim CYP1A2 sehingga dapat meningkatkan efek warfarin melalui jalur penghambatan enzim pemetabolisme [37]. Studi sebelumnya menunjukkan bahwa interaksi antibiotik melalui jalur penghambatan 
Tabel 5. Penggunaan antibiotik pada pasien dengan kejadian perdarahan pasca rawat inap

\begin{tabular}{lcc}
\multicolumn{1}{c}{ Antibiotik saat rawat inap } & Antibiotik saat dipulangkan & Penggunaan antibiotik kombinasi \\
\hline Seftriakson, Azitromisin, Siprofloksasin & Siprofloksasin & Seftriakson, Azitromisin \\
Seftriakson, Seftazidim & Tidak ada & Tidak ada \\
Seftriakson, Azitromisin, Sefiksim & Sefiksim & Seftriakson, Azitromisin \\
Ampisilin-sulbaktam & Tidak ada & Tidak ada \\
\hline
\end{tabular}

metabolisme hepatik akan memberikan dampak yang lebih besar dibandingkan interaksi melalui jalur gangguan pada sintesis vitamin K [11]. Perbandingan antar kelompok antibiotik pada studi ini belum dapat dilakukan karena terbatasnya besar sampel penelitian,.

Tipe infeksi yang dialami pasien dipaparkan dalam Tabel 4. Infeksi saluran napas bawah merupakan infeksi yang paling sering diderita $(37,9 \%)$ disusul dengan infeksi saluran kemih (20,7\%). Pasien dengan kejadian perdarahan tercatat mengalami infeksi saluran nafas bawah (75\%) dan tidak diketahui (25\%). Hal ini selaras dengan sebuah penelitian yang mengungkapkan bahwa tipe infeksi mungkin berpengaruh terhadap perbedaan peningkatan INR pada jenis antibiotik tertentu. Pasien dengan fluorokuinolon yang mengalami infeksi saluran nafas bawah dan infeksi saluran kemih dilaporkan mengalami peningkatan nilai INR, tidak seperti pasien dengan fluorokuinolon untuk indikasi infeksi kulit dan jaringan lunak [13]. Kejadian infeksi dan komplikasinya seperti demam dan kurangnya asupan vitamin $\mathrm{K}$ diasumsikan dapat meningkatkan risiko perdarahan [15]. Meskipun begitu studi lain juga menyatakan bahwa infeksi saja tanpa penggunaan antibiotik dengan risiko tinggi perdarahan tidak mempengaruhi risiko kejadian perdarahan pada pengguna warfarin [9].

Penelitian ini memiliki beberapa keterbatasan. Pertama, penelitian ini hanya menilai kejadian perdarahan sebagai luaran klinik tanpa mempertimbangkan perubahan nilai INR. Perbandingan nilai INR, yang merupakan parameter untuk mengukur aktivitas antitrombotik warfarin [5,8], akan lebih memastikan bahwa kejadian perdarahan memang terkait dengan modifikasi aktivitas antikoagulasi tersebut. Kedua, studi ini tidak mempertimbangkan perubahan dosis warfarin yang terjadi sebelum masa observasi. Perubahan dosis warfarin akan berpengaruh terhadap nilai INR dan merupakan salah satu strategi dalam manajemen perdarahan atau peningkatan nilai INR [5,8] sehingga dapat mempengaruhi hasil penelitian. Ketiga, studi ini juga tidak menilai adanya kemungkinan interaksi warfarin dengan makanan. Fluktuasi asupan vitamin K harian dari diet dapat berpengaruh terhadap aktivitas antikoagulasi warfarin sehingga dapat berpengaruh terhadap risiko kejadian perdarahan [38]. Keterbatasan keempat yaitu studi ini tidak mempertimbangkan adanya variasi genetik antar pasien. Berdasarkan studi sebelumnya, variasi genetik dilaporkan turut berpengaruh terhadap perbedaan sensitivitas warfarin antar pasien pada populasi Indonesia [39]. Keterbatasan selanjutnya, terkait dengan tidak adanya kejadian perdarahan pada kelompok kontrol, maka nilai risiko relatif pada studi ini menjadi tidak terhingga. Penelitian lanjutan dengan memperbanyak jumlah subjek dan mempertimbangkan faktor genetik akan lebih baik dalam menganalisis keterkaitan antara interaksi warfarin dan antibiotik dengan kejadian perdarahan pada populasi Indonesia.

\section{Kesimpulan}

Penggunaan antibiotik saat rawat inap dapat meningkatkan risiko kejadian perdarahan dalam waktu tujuh hari pasca pasien dipulangkan. Antibiotik yang digunakan oleh pasien dengan kejadian perdarahan yaitu azitromisin, ampisilin-sulbaktam, golongan sefalosporin, dan golongan kuinolon.

\section{Ucapan Terima Kasih}

Terimakasih kepada Lembaga Pengelola Dana Pendidikan (LPDP) Kementerian Keuangan RI yang telah mendanai penelitian ini melalui komponen Dana Tesis pada Beasiswa Pendidikan Indonesia Program Magister dengan nomor LPDP 201907110814771.

\section{Referensi}

[1]. Kementerian Kesehatan. Keputusan Menteri Kesehatan Republik Indonesia Nomor HK.01.07/Menkes/813/2019 tentang Formularium Nasional. Jakarta: Kementerian Kesehatan Republik Indonesia; 2019 Dec p. 154. 
[2]. Kuruvilla M, Gurk-Turner C. A review of warfarin dosing and monitoring. Proceedings (Baylor University Medical Center). 2001;14(3):305. https://doi.org/10.1080/08998280.2001.11927 781

[3]. Chai-Adisaksopha C, Hillis C, Isayama T, Lim W, lorio A, Crowther M. Mortality outcomes in patients receiving direct oral anticoagulants: a systematic review and meta-analysis of randomized controlled trials. Journal of Thrombosis and Haemostasis. 2015;13(11):2012-20. https://doi.org/10.1111/ith.13139

[4]. Linkins L-A, Choi PT, Douketis JD. Clinical Impact of Bleeding in Patients Taking Oral Anticoagulant Therapy for Venous Thromboembolism: A Meta-Analysis. Ann Intern Med. 2003;139(11):893. https://doi. org/10.7326/0003-4819-139-11-200312020-00007

[5]. Ageno W, Gallus AS, Wittkowsky A, Crowther M, Hylek EM, Palareti G. Oral Anticoagulant Therapy. Chest. 2012;141(2):e44S-e88S. https://doi.org/10.1378/chest.11-2292

[6]. Hylek EM, Go AS, Chang Y, Jensvold NG, Henault LE, Selby JV, et al. Effect of Intensity of Oral Anticoagulation on Stroke Severity and Mortality in Atrial Fibrillation. New England Journal of Medicine. 2003;349(11):1019-26. https://doi.org/10.1056/NEJMoa022913

[7]. Ansell J, Hirsh J, Hylek E, Jacobson A, Crowther M, Palareti G. Pharmacology and Management of the Vitamin K Antagonists. Chest. 2008;133(6):160S-198S. https://doi.org/10.1378/chest.08-0670

[8]. Holbrook A, Schulman S, Witt DM, Vandvik PO, Fish J, Kovacs MJ, et al. Evidence-Based Management of Anticoagulant Therapy. Chest. 2012;141(2):e152S-e184S. https://doi.org/10.1378/ chest.11-2295

[9]. Lane MA, Zeringue A, McDonald JR. Serious Bleeding Events due to Warfarin and Antibiotic Co-prescription in a Cohort of Veterans. The American Journal of Medicine. 2014;127(7):657-663.e2. https:// doi.org/10.1016/i.amimed.2014.01.044

[10]. Martín-Pérez M, Gaist D, de Abajo F, Rodríguez L. Population Impact of Drug Interactions with Warfarin: A Real-World Data Approach. Thromb Haemost. 2018;118(03):461-70. https://doi. org/10.1055/s-0038-1627100

[11]. Clark NP, Delate T, Riggs CS, Witt DM, Hylek EM, Garcia DA, et al. Warfarin Interactions With Antibiotics in the Ambulatory Care Setting. JAMA Intern Med. 2014;174(3):409. https://doi. org/10.1001/jamainternmed.2013.13957

[12]. Hogg K, Weitz JI. Blood Coagulation and Anticoagulant, Fibrinolytic, and Antiplatelet Drugs. In: Brunton L, Knollman B, Hilal-Dandan $\mathrm{R}$, editors. Goodman and Gilman's The Pharmacological Basis of Therapeutics, 13th Edition. McGraw Hill Professional; 2018. p. 585603.

[13]. Ghaswalla PK, Harpe SE, Tassone D, Slattum PW. Warfarin-Antibiotic Interactions in Older Adults of an Outpatient Anticoagulation Clinic. The American Journal of Geriatric Pharmacotherapy. 2012;10(6):35260. https://doi.org/10.1016/j.amjopharm.2012.09.006

[14]. Baillargeon J, Holmes HM, Lin Y-L, Raji MA, Sharma G, Kuo Y-F. Concurrent Use of Warfarin and Antibiotics and the Risk of Bleeding in Older Adults. The American Journal of Medicine. 2012;125(2):1839. https://doi.org/10.1016/i.amimed.2011.08.014

[15]. Schelleman H, Bilker WB, Brensinger CM, Han X, Kimmel SE, Hennessy S. Warfarin - Fluoroquinolones, Sulfonamides, or Azole Antifungals Interactions and the Risk of Hospitalization for Gastrointestinal Bleeding. Clin Pharmacol Ther. 2008;84(5):581-8. https://doi.org/10.1038/clpt.2008.150

[16]. Clark TR, Burns S. Elevated International Normalized Ratio values associated with concomitant use of warfarin and ceftriaxone. American Journal of Health-System Pharmacy. 2011;68(17):1603-5. https://doi.org/10.2146/ajhp100681

[17]. Saum LM, Balmat RP. Ceftriaxone Potentiates Warfarin Activity Greater Than Other Antibiotics in the Treatment of Urinary Tract Infections. Journal of Pharmacy Practice. 2016;29(2):121-4. https:// doi.org/10.1177/0897190014544798

[18]. Agustini TT, Arifin H, Hanif AM. Perbandingan Dosis Warfarin terhadap Durasi Tercapainya Target INR pada Pasien CHF dengan Fibrilasi Atrial. JSainsFarKlin. 2016;2(2):162. https://doi. org/10.29208/jsfk.2016.2.2.67
[19]. Ningrum VDA, Sufiyah S, Dyah Widyastuti I, Sufriyanto Yusuf B, Dullah W. Bleeding Incidence in Patients Administered with Warfarin at Secondary Hospitals in Yogyakarta Province. Indonesian J Pharm. 2020;217. https://doi.org/10.22146/ijp.814

[20]. Lemeshow S, Hosmer DW, Klar J, Lwanga SK, Organization WH. Adequacy of sample size in health studies [Internet]. Chichester: Wiley; 1990. Available from: https://apps.who.int/iris/ handle/10665/41607

[21]. Kearon C, Akl EA, Ornelas J, Blaivas A, Jimenez D, Bounameaux H, et al. Antithrombotic Therapy for VTE Disease. Chest. 2016;149(2):31552. https://doi.org/10.1016/j.chest.2015.11.026

[22]. Shendre A, Parmar GM, Dillon C, Beasley TM, Limdi NA. Influence of age on warfarin dose, anticoagulation control, and risk of hemorrhage. Pharmacotherapy. 2018;38(6):588-96. https://doi. org/10.1002/phar.2089

[23]. Chen W-C, Chen Y-H, Hsu P-I, Tsay F-W, Chan H-H, Cheng J-S, et al. Gastrointestinal Hemorrhage in Warfarin Anticoagulated Patients: Incidence, Risk Factor, Management, and Outcome. BioMed Research International. 2014;2014:1-7. https://doi. org/10.1155/2014/463767

[24]. Zhang K, Young C, Berger J. Administrative Claims Analysis of the Relationship Between Warfarin Use and Risk of Hemorrhage Including Drug-Drug and Drug-Disease Interactions. JMCP. 2006;12(8):640-8. https://doi.org/10.18553/imcp.2006.12.8.640

[25]. Shoeb M, Fang MC. Assessing Bleeding Risk in Patients Taking Anticoagulants. J Thromb Thrombolysis. 2013;35(3):312-9. https:// doi.org/10.1007/s11239-013-0899-7

[26]. Olesen JB, Lip GYH, Hansen PR, Lindhardsen J, Ahlehoff O, Andersson $\mathrm{C}$, et al. Bleeding risk in 'real world' patients with atrial fibrillation: comparison of two established bleeding prediction schemes in a nationwide cohort. Journal of Thrombosis and Haemostasis. 2011;9(8):1460-7. https://doi.org/10.1111/j.15387836.2011.04378.x

[27]. Nieto JA, Solano R, Ruiz-Ribó MD, Ruiz-Gimenez N, Prandoni P, Kearon $C$, et al. Fatal bleeding in patients receiving anticoagulant therapy for venous thromboembolism: findings from the RIETE registry. Journal of Thrombosis and Haemostasis. 2010;8(6):121622. https://doi.org/10.1111/i.1538-7836.2010.03852.x

[28]. Holbrook AM. Systematic Overview of Warfarin and Its Drug and Food Interactions. Arch Intern Med. 2005;165(10):1095. https:// doi.org/10.1001/archinte.165.10.1095

[29]. Westenbrink BD, Alings M, Granger CB, Alexander JH, Lopes RD, Hylek EM, et al. Anemia is associated with bleeding and mortality, but not stroke, in patients with atrial fibrillation: Insights from the Apixaban for Reduction in Stroke and Other Thromboembolic Events in Atrial Fibrillation (ARISTOTLE) trial. American Heart Journal. 2017;185:140-9. https://doi.org/10.1016/j.ahj.2016.12.008

[30]. Kruse-Jarres R. Acquired bleeding disorders in the elderly. Hematology. 2015;2015(1):231-6. https://doi.org/10.1182/ asheducation-2015.1.231

[31]. The GUSTO Investigator. An International Randomized Trial Comparing Four Thrombolytic Strategies for Acute Myocardial Infarction. New England Journal of Medicine. 1993;329(10):673-82. https://doi.org/10.1056/NEJM199309023291001

[32]. Liaqat, Khan, Asad, Khalil. Effect of Quinolones Versus Cefixime on International Normalized Ratio Levels After Valve Replacement Surgery with Warfarin Therapy. Medicina. 2019;55(10):644. https:// doi.org/10.3390/medicina55100644

[33]. Carroll DN, Carroll DG. Interactions Between Warfarin and Three Commonly Prescribed Fluoroquinolones. Ann Pharmacother. 2008;42(5):680-5. https://doi.org/10.1345/aph.1K605

[34]. Stroud LF, Mamdani MM, Kopp A, Bell CM. The safety of levofloxacin in elderly patients on warfarin. The American Journal of Medicine. 2005;118(12):1417.e7-1417.e12. $\quad$ https://doi.org/10.1016/j. amjmed.2005.06.066 
[35]. Abdel-Aziz MI, Ali MAS, Hassan AKM, Elfaham TH. Warfarin-drug interactions: An emphasis on influence of polypharmacy and high doses of amoxicillin/clavulanate: Influence of polypharmacy and high doses of amoxicillin/clavulanate on warfarin. The Journal of Clinical Pharmacology. 2016;56(1):39-46. https://doi.org/10.1002/ jcph.583

[36]. MacDougall C. Penicillins, Cephalosporins, and Other $\beta$-Lactam Antibiotics. In: Brunton L, Knollman B, Hilal-Dandan R, editors. Goodman and Gilman's The Pharmacological Basis of Therapeutics, 13th Edition. McGraw Hill Professional; 2018. p. 585-603.

[37]. Israel DS, Stotka J, Rock W, Sintek CD, Kamada AK, Klein C, et al. Effect of Ciprofloxacin on the Pharmacokinetics and Pharmacodynamics of Warfarin. Clinical Infectious Diseases. 1996;22(2):251-6. https:// doi.org/10.1093/clinids/22.2.251
[38]. Holmes MV, Hunt BJ, Shearer MJ. The role of dietary vitamin K in the management of oral vitamin $\mathrm{K}$ antagonists. Blood Reviews. 2012;26(1):1-14. https://doi.org/10.1016/j.blre.2011.07.002

[39]. Suriapranata IM, Tjong WY, Wang T, Utama A, Raharjo SB, Yuniadi Y, et al. Genetic factors associated with patient-specific warfarin dose in ethnic Indonesians. BMC Med Genet. 2011;12:80. https://doi. org/10.1186/1471-2350-12-80.

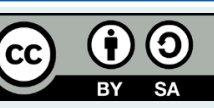

Copyright $\odot 2021$ The author(s). You are free to share (copy and redistribute the material in any medium or format) and adapt (remix transform, and build upon th material for any purpose, even commercially) under the following terms: Attribution - You must give appropriate credit, provide a link to the license, and indicate if transform, or build upon the material, you must distribute your contributions under the same license as the original (https://creativecommons. org/licenses/by-sa/4.0/) 